\title{
„Krakowski kolaż. 60. rocznica powstania \\ Kabaretu Piwnica pod Baranami 1956-2016" - wystawa zorganizowana przez Archiwum Narodowe w Krakowie
}

W 2016 r. legendarny krakowski Kabaret „Piwnica pod Baranami” świętował 60. rocznicę swojego powstania. Obchody jubileuszowe stały się doskonałą okazją do prezentacji ciekawego i mało znanego fragmentu zasobu Archiwum Narodowego w Krakowie zgromadzonego w zbiorze „Piwnica pod Baranami” i jej ludzie oraz aktach Krakowskiego Domu Kultury „Pałac pod Baranami” w Krakowie. Wspomniane archiwalia uzupełniono o dokumentację Stowarzyszenia Artystów i Sympatyków „Piwnicy pod Baranami” oraz fotografie, rysunki i materiały audiowizualne z prywatnych kolekcji.

Ekspozycję „Krakowski kolaż...” przygotowano w pięciu odsłonach mówiących o powstaniu Kabaretu w okresie poststalinowskiej odwilży, jego oryginalnym repertuarze, problemach z cenzurą, znakomitych artystach oraz o świętowaniu, które jak twierdził Piotr Skrzynecki - spiritus movens „Piwnicy pod Baranami”, stanowi istotę życia. Przypomniano słynne bale, obchody okragłych i nieokragłych jubileuszy piwnicznych oraz historyczne inscenizacje organizowane przez Kabaret. Ostatnią część wystawy poświęcono czasom współczesnym - najnowszej historii Kabaretu liczonej od 1997 r. - stanowiącego moment przełomowy w dziejach tej sceny, gdy po śmierci P. Skrzyneckiego ważyły się jej losy. Opowieść o nowych programach i zgodnym współdziałaniu na scenie trzech pokoleń artystów przygotowali obecni twórcy Kabaretu, kontynuujący dzieło swoich poprzedników.

Wiele miejsca poświęcono sylwetkom Janiny Garyckiej, piwnicznej scenografki i jej wieloletniego kierownika literackiego, oraz P. Skrzyneckiego, dyrektora, konferansjera i reżysera. Całość wystawy zaprezentowana została niejako przez pryzmat tych osób, gdyż materiały przez nich wytworzone lub przez nich zebrane, przechowywane w Archiwum Narodowym w Krakowie, stały się podstawą tej ekspozycji. Cytaty z ich wypowiedzi utrwalone na taśmie filmowej, na łamach prasy oraz w prywatnych notatkach doskonale zilustrowały pierwsze 40 lat działalności „Piwnicy”. Nakreślono również złożone portrety pozostałych artystów, a także sympatyków Kabaretu, który w drugiej połowie XX w. stał się prawdziwą kuźnią talentów. Wywiady z twórcami i przyjaciółmi Kabaretu udostępnione za pośrednictwem kodów QR pozwoliły na poznanie jego historii w różnych narracjach. To właśnie kolaż złożony z osobowości związanych z „Piwnicą” wspaniałych artystów, znakomitego repertuaru oraz wiernej publiczności zdecydował o długowieczności i unikalności tej wyjątkowej sceny kabaretowej.

Sześćdziesiąte urodziny Kabaretu skłoniły do przyjrzenia się bliżej świętowaniu „piwnicznych jubileuszy", z których każdy posiadał unikatową tematykę i niepowtarzalną oprawę. Na dłużej zatrzymano się w tej części przy obchodach jubileuszu sprzed 30 lat, w ramach których zorganizowano Wielką Wystawę Jubileuszową „I co nam z tego zostało...” w Pałacu Sztuki oraz bal w Krakowskim Domu Kultury pod hasłem „Przypomnij sobie 
pierwsze miesiące 1956 r. ...”. Obecna wystawa w dużej mierze nawiązuje właśnie do tamtych wydarzeń widzianych z perspektywy kolejnych pokoleń.

Podczas ekspozycji „Krakowski kolaż...” na dwudziestu planszach wielkoformatowych zaprezentowano wykonane na przestrzeni kilku dekad fotorelacje z przedstawień kabaretowych oraz fotografie artystów autorstwa między innymi Ryszarda Horowitza, Zbigniewa Łagockiego, Tadeusza Płaszewskiego i Bogdana Zimowskiego; fragmenty znakomitego repertuaru, który uczynił z „Piwnicy” najbardziej znany kabaret artystycznoliteracki w Polsce, a także wyselekcjonowane plakaty, ulotki, zaproszenia, okolicznościowe bibeloty i balowe rekwizyty. Właśnie poprzez dobór eksponatów i sposób ich prezentacji oraz ciekawą oprawę graficzną, wystawa utrzymana została w stworzonej przez „Piwnicę” oryginalnej estetyce. Próbie uchwycenia charakterystycznego „piwnicznego stylu” sprzyjało wykorzystanie znakomitych rysunków i grafik Kazimierza Wiśniaka, Jerzego Skarżyńskiego, Kazimierza Madeja, Sebastiana Kudasa, czy wreszcie J. Garyckiej.

Wystawa przygotowana w polskiej i angielskiej wersji językowej została zaadresowana nie tylko do wiernych miłośników wciąż działającego Kabaretu, lecz przede wszystkim do osób z młodego pokolenia, którym postacie piwnicznych artystów i dawny repertuar są już często zupełnie nieznane. Celem wystawy było przypomnienie korzeni wciąż działającego Kabaretu i pokazanie zwiedzającym, jakim fenomenem była Piwnica na scenie kulturalnej PRL.

Ekspozycję zaprezentowano na Placu Szczepańskim w Krakowie (13-27 czerwca 2016 r.) oraz na dziedzińcu wewnętrznym Archiwum przy ul. Siennej 16 (1 lipca - 10 października 2016 r.). W dniach 2-30 listopada 2016 r. plansze gościły na 8. Festiwalu Piotra Skrzyneckiego w Mińsku Mazowieckim.

Uroczysty wernisaż wystawy 16 czerwca 2016 r. z udziałem władz miasta, środowisk twórczych i licznie przybyłych miłośników „Piwnicy pod Baranami” połączony został z koncertem artystów kabaretowych na Placu Szczepańskim oraz w podziemiach Pałacu Potockich pod Baranami - Rynek Główny 27 - siedzibie Kabaretu.

W ramach działań związanych z finisażem wystawy przygotowano promocję bogato ilustrowanego katalogu zawierającego wybór materiałów prezentowanych na wystawie opatrzonych obszernym komentarzem, który pozwala na poznanie historii „Piwnicy” w efektownej formie.

Fragment ekspozycji zatytułowany „Piwnica pod Baranami Janiny i Piotra” został również udostępniony online w postaci wirtualnej wystawy dostępnej na stronie domowej Archiwum http://www.ank.gov.pl/wystawy-i-galerie/krakowski-kolaz.

Wystawa „Krakowski kolaż. 60. rocznica powstania Kabaretu Piwnica pod Baranami 1956-2016" została zrealizowana we współpracy ze Stowarzyszeniem Artystów i Sympatyków Piwnicy pod Baranami oraz dzięki dofinansowaniu Naczelnego Dyrektora Archiwów Państwowych, przy udziale Gminy Miejskiej Kraków.

Lilianna Pochwalska Archiwum Narodowe w Krakowie 